\title{
The Impact of Aligning the Strategies of CREM with Those of a Corporate Business Using Real Options*
}

\author{
Singita Makaringi ${ }^{1}$, Khabane Mokoka $^{1} \&$ Jake Schmidt $^{1}$ \\ ${ }^{1}$ School of Construction Economics \& Management, WITS University, Johannesburg, 2000, South Africa \\ Correspondence: School of Construction Economics \& Management, WITS University, Johannesburg, 2000, South \\ Africa
}

Received: August 22, 2018

Accepted: October 2, $2018 \quad$ Available online: October 11, 2018

doi:10.11114/afa.v5i1.3684

URL: https://doi.org/10.11114/afa.v5i1.3684

\begin{abstract}
The article investigates the benefits of incorporating corporate real estate management (CREM) in the main business units of the company. Prior studies have illustrated that CREM unit in major companies is treated as a separately entity with less focus on its contribution to maximization of shareholders' wealth. This article uses real option approach, specifically Samuelson-McKean (1965) model to extrapolate the value of CREM of listed South African insurance company. The results show that when CREM is insourced and treated as a significant part of the main insurance, shareholders' wealth is maximised-value of the company increases, total costs are managed and financial parameters increase investment value-volatility can be as high as $100 \%$. Although, the data is on financial services, the results can be replicated in other industries given that the analysed company has exposure to a number of industries.
\end{abstract}

Keywords: corporate real estate management, real option

JEL: G12, R33

\section{Introduction to the Study}

\subsection{Introduction}

The real estate industry has been growing over the past years and one visible area of growth is in the concept of managing CRE as part of the core business instead of an appendage costly necessity for the business. In the past the real estate that the business held was seen as a cost that needed immediate mitigation and nothing else. The managing of CRE estate is a concept that has developing over the years and recently puts forth the idea that CREM is a functional unit of the business organization (Alli et al, 2008) that not only supports the operations of the business (Krumm and Linneman, 2001) but optimally uses all real estate assets available to the business in pursuit of the core business objectives, vision and mission. Firms still had the option to manage their real estate in-house or perhaps co-source (a much more recent phenomenon) but at the time this was seen as not viable.

Moving on to more recent ideas Gibler and Lindholm, (2012) view CREM as more focused on strategic practices with adding that the strategy that is mostly at the core of effective real estate management is one that aligns the CRE strategy to the core business's strategy which in turn maximizes the value added and thus contributing to the overall performance of the corporation. Today it is know that investors are able to use real options to maximize their firms' value. As this may be so they still find themselves face with challenges of careful planning and aligning of strategies that go into the decision making of what asset to own or dispose of, what to do with an asset, why choose that specific asset, and when and how to carry it to ensure that it gives the maximum return to the shareholder or firm. Real estate assets require large capital investments in nature and thus it is imperative that the correct strategies are implemented as these can have consequential monetary value and in turn affect the value greatly.

It is mostly best to wait for more favourable variables to enter the market in order to minimize risk and maximize value. This is where CREM comes in, it selects the best and highest value option for an asset and it bases this on changing

\footnotetext{
* We are grateful to insightful comments of two anonymous reviewers and Tumellano Sebehela which improved this article. The remaining errors are our own. T +27(0)11 717-7669, E 712595@students.wits.ac.za (K. Mokoka), 673259@ students.wits.ac.za (S. Makaringi) and jakeschmidt3@gmail.com (J. Schmidt).
} 
market influences, such as interest rates and hurdle rates. To deduce which real option is better for the cause of action at hand an analysis needs to be carried out and this requires the understanding of how real options work and they are affected by and some of the variables that need to be understood amongst others are the effect of different costs, output elasticity and uncertainty.

Therefore, this paper will observe the behaviour of options in the presence of cost and in the absence of costs and determine how the interest rate, spot price, exercise price, time to maturity and underlying assets behave in terms of real options in CREM. This paper seeks out to determine if the kind of CREM being practised in a firm holds any bearing in its value worth and if the analysis introduced by using real options does indeed increase the firms and shareholders value.

Prior studies have illustrated that CRE and the rest of companies business units are misaligned; therefore, shareholders' wealth is not maximised. The article contributes to the body of knowledge by using real options in maximised the shareholders wealth by harmonising CRE with the rest of the business units. Real options are used in this study as they appropriately handle flexibility of assets. In order to synthesis the contribution, this article answers three objectives:

(i) To investigate if insourcing and accounting for CREM increases the companies value and wealth for shareholders.

(ii) The impact of revenues and/or costs on the company's value.

(iii) To understand the extent of the sensitivity of company value to interest rates.

The rest of the article is organised as follows. Section 2 is on literature review. Section 3 is on methodology. Section 4 is on data and section 5 on the analysis. Section 6 concludes the article.

\section{Literature Review}

In review prior studies, this study focuses on the benefits, outsourcing and insourcing of CREM.

\subsection{Benefits of CREM}

De Jonge (1996) described some of the elements that add value of real estate and this element are still relevant today. Further, he explains that the overall benefit of having a management division in one's firm is that it can increase productivity by location the best suited site selection for the business in accordance to its core business or it can introduce alternative workplaces which result in minimum absences of leave form employees or the users of the space. Other benefits of CREM includes reducing cost by creating insight into cost structure, making more efficient use of workplaces and by controlling costs of financing. It has control over risk by retaining a flexible real estate portfolio, selecting suitable locations and by controlling the value development of the real estate portfolio. Increase in value is achieved by conducting timely purchase and sale of real estate redevelopment of obsolete properties and through gaining knowledge and insight of real estate markets. Increase in flexibility through organizational measures including legal or financial measures, by changing the culture and introducing workplace innovations. Lastly PR and marketing by managing the selection of branch locations, image of buildings and governing corporate identity.

\subsection{Outsourcing CREM}

Most firms believe that if they hand over their CREM responsibilities this will allow the company to focus on the corporate business without having to worry about the real estate of it. Outsourcing CREM has its rewards but the negative impact has far more greater consequence. Firms can also choose to manage their real estate in-house or perhaps co-source (Gibler and Black, 2004).

Outsourcing is a method of hiring another person to perform your functions and your responsibilities. Gibler and Black (2004) suggest that outsourcing can indeed increase returns but this is only for the short-term and not the long term, they argue that in the long term outsourcing decrease the acquired benefits that where accumulated in the short-term. As much as outsourcing can control cost, give a competitive advantage, have access to technology and skills it still incurs negatives that are hard to overlook (Matsham and Heywood, 2012). Gibler and Black (2004) suggest that the challenge faced with outsourcing is that because the service provider deems its self an expert in matters of real estate management it may neglect to communicate with the client when making decisions and this may lead to the miscommunication on how the client wants to use their real estate furthermore the service provider may be making assumptions on what the client wants without first understanding the corporate needs and culture.

\subsection{Insourcing CREM}

Matsham and Heywood (2012) suggest that in-house management is most likely to manage these sub-functions; leasing and development, client relationship management and acquisition, portfolio management, financial analysis and strategic planning. CREM teams are most likely to understand the business goals and objectives meaning it can align these with its own, resulting in the company achieving its goals and objectives. 
It requires the employment of more stuff which then results in higher costs and a strong team to manage/oversee the operations. Permanent employment minimizes the level of accountability amongst employees as the consequence of this is unlike outsourcing where for example poor performance can lead to loss of employment and reputation. As the business standing may change from time to time employees may find it difficult to change with it causing retraining, redevelopment or even layoffs which may negatively affect the investors and local communities. It limits the interaction with other industry specialist as the management is in-house. One of the major threats that in-house management faces is complacency and this is easily noticed by clients/customers. The alignment of the two strategies will be to see to it that the business strategies and those of CRE are coordinated and not conflicting, that the vision of one strategy does not hinder the progress of the other but actually support it.

This section dwells into how certain variables affect land options as an investment in order to maximize shareholders value. This section focuses on corporate strategy and looks at how specific variables can change the best investment strategies in terms of the companies' options to invest in their land in order to make the best strategic decision to maximize value. In order to maximize shareholders value, we believe CRE strategy must be aligned with the land option investment strategy. We will be looking at the variables namely; interest rates, hurdle rates and the timing of the decision and how these variables affect investor's real options in different situations. I will now define these variables in order to analyse their effect on a company's real land options. For this research report, the focus is on land options as the report explores how land options are maximised in the context of CREM strategies. In the typical development project (or parcel of developable land), there are three major types of options and some of them include (a) wait option: the option to delay start of the project start of the project construction (Arnold and Crack 2000), (b) phasing option: the breaking of the project into sequential phases rather than building it all at once rather than building it all at once (Arnold and Crack 2000) and (c) switch option: the option to choose among alternative types of buildings to construct on the given land parcel of buildings to construct on the given land parcel.

Today it is known that an investor is able to us their land options as a real option in order to maximize shareholders and companies value. Land is a major capital investment and thus it is imperative to have the correct land development strategy as a small variable can have huge monetary affects and in turn affect the value greatly. Sometimes it is best to wait for more favourable developer variables to enter the market in order to minimize risk and maximize value. Part of CREM is selecting the best and highest value land option for a site. Based on changing market influences, such as interest rates and hurdle rates, investors should know when to develop and when to wait. These influences affect the land options on a company can dispose of land. Land options as a real option, looks at the opportunity costs of building as opposed to waiting/delaying the development process and taking out the process at a different time. Many papers conclude on the massive investment savings made by choosing the correct time to develop land (land options) based on the forecasted future market influences. It is highly important to look at all the data available and make a correct land option decision due to the magnitude of land assets. Thus we can see land options as a real investment option and we can aid profit maximization by analysing all the available land options before developing.

\subsection{Real Options}

\subsubsection{General Background on Real Options}

Options is a term that was chosen for the significance of understanding the theory of real options, as it is a right, but one is not obliged to use it for decision making unless if it is used to pass value for the decision maker by undertaking a future action on a real (underlying) asset. However, there are various types of real options: deferral option, the option to grow, switching option, and the option to abandon (Damaraju, Barney and Makhija, 2015). Damaraju, Barney and Makhija (2015) state that decision making of real options provides positive aspects and enhances the value of flexibility for a corporation when there are positive outcomes in uncertain events which allows for new information to make available models far better for land use investment behaviour, while the corporation's losses can be lessened when uncertain events bring forth negative outcomes (Regan et al. 2015). The literature review will go on to explain the different behavioural aspects of options while focusing on various factors mentioned above.

The approach to real options has been discovered to face numerous complications with its application strategy in quantitative models. Bowman and Moskowitz (2001) considered these complications to fall under (1) finding models that correspond to projects under evaluated, (2) finding the inputs for that specified model, and (3) explaining the option pricing procedure mathematically. For some cases, increases in real options are affected by the changes of interest rates and other variables; significantly this shows how values vary as per timing, taxes, and growth expectations. Put options are affected by interest rates in various ways. For example, they affect the lower bound; if the lower bound is high then the interest rate is low indicating the higher present value $(\mathrm{PV})$ of the exercise price. As well as when exercising a put option (selling stock to receive $\mathrm{X}$ amount of Rands) the lower the interest rates the higher the PV of the cash (X Rands) making the put more attractive to investors. 


\subsubsection{General Behaviour of Options in the Absence of Costs}

Lambrecht and Perraudin (2003) stated that the implications of the firms in the environment of real investments are the timing, which differs in degrees of imperfect information and competition. The behaviour of pre-emptive and incomplete information determines the richness of the implications. Cox et al. (1979) states Black-Scholes (B-S) method is mathematically advanced and may at times be difficult to use for values of the underlying economics. Therefore, this dissertation will observe the behaviour of options in the absence of costs and determine how the interest rate, spot price, exercise price, time to maturity and underlying assets behave in terms of land options in CREM. Decisions on land use and management investments can be categorised by alteration, uncertainty and irreversibility (Regan et al, 2015). Regan et al. (2015) states that real options analysis (ROA) is the recommended valuation approach with regards to change.

(a) Types of Investment Opportunities

Regan et al. (2015) state that the NPV of an investment must not only be positive, it must have returns that exceed the expected deferred investment from the expected returns invested now. Riskless interest is equal for both lenders and borrowers and is known to remain constant over the years. Sebehela (2009), shows how Capozza and Li (1994) observes the increase of real interest rate in a long call option to increase the option value implying lower capital intensity, while in the long put option the option value decreases implying higher capital intensity as a result of interest rates decreasing.

Researchers also look at the time to expiration defined as the time to build a property, which is affected by the ease of access of all building material together with the risk related with the attainment of all building material. Hence, the total value of the option varies over time. Chiang et al. (2006) stated that the longer it takes to build a property, the higher the option value and the volatility of the underlying (real) asset. Martins et al. (2013) mentioned how prior studies observed the difference in real options and financial options; an underlying financial asset would hold a right to dispose or purchase at a possibly favourable value and at a profitable trade. According to Martins et al. (2013), the underlying asset value can be affected by the owner of the real option and simultaneously, the value of an underlying asset can be improved by the operation manager. Real options compared to financial options have different analogies, where real options' time to maturity is viewed as the "time until the investment opportunity disappears" (Martins et al, 2013). In the case that the option is exercised after the time to expiration, the options losses the value that the venture capitalist would have gained before maturity. The longer lived option is at its maximum in the time of its minimum value; unless it has no time value then its price is insignificant as of a short lived option at the time of expiration with the same terms.

(b) Implementation of Options

It is evident that most researchers observe the various types of options under certain circumstances and focus on a single variable at a time in an isolated valuation. Strategic options develop over time through countless investment opportunities that arise and there is flexibility in many investment decisions prepared under changes that know how to acquire considerable value (Regan et al. 2015). There is very little research that dwells on implementation of the option(s) in an organisational environment. Thus, there is a need to focus on managerial options, as well as the exercise of real options in the management divisions (Trigeorgis and Reuer, 2017). This will provide sufficient information on the exercising of options and allow for the decision makers to have great quality of strategic reasoning that is closely related to the organisational environment. However, even in the organisations, ROA is a complex practice and has intended that taking on these practices is random (Regan et al. 2015).

Land use and management investments with risks that can be addressed throughout all construction stages can have simpler approaches that will provide sufficient information, whereas intricate investments difficulties requires the creation of advanced models that are better match ups for the investments and consider many uncertainties due to its adaptation (Bowman and Moskowitz, 2001). Although as these models are challenging to form and mathematically solve the options, these advanced approaches are not often used for strategic investment decisions. Although Bowman and Moskowitz (2001) consider the value of investment decisions to lie in the condition for consistency as the value of ROA frequently originates from project strategy implications, instead of the tangible planning valuation. The benefit of using ROA is that it could possibly alter the revised types of investment offers. Thus, more similar investments can be considered to use the same real options to analyse the proposals. Bowman and Moskowitz (2001) also state that strategic options inspires investigation and conducting tests under uncertain events in the process of investment decision making.

\subsubsection{General Behaviour of Options in the Presence of "Costs"}

\section{(a) Does Uncertainty Increase the Value of Conversion?}

Time and again landowners find themselves faced with decision challenges when it comes to what they can do with their land and this is not only because they do not know what to do with the land in their possession but as to what is the 
best possible way to use the property in order to maximise on its value. For one to be able to know which option is the best an analysis has to be done, part of the analysis require the understanding of how value options will be affected by total cost variable cost, fixed costs, output elasticity, construction cost and uncertainty. The analysis done by Titman (1985), demonstrates that in a case of a vacant land the increase in the level of uncertainty leads to the decrease of building activity of that particular period. While one may opt to wait until such certainties are minimised the option to wait has its own consequences and, that is, one may miss the opportunity presented by that particular period or simply benefit from waiting as this gives the chance of building a more appropriate building for the future.

(b) Do Fixed Costs Have an Impact on Value Options?

In economic principles suggest that fixed cost are not affected by changes in the level of activity within an operation at a particular time but stresses that during periods of high levels of change the fixed cost can vary significantly. The amount of leverage in this instance is random and this is because it increases while the underlying value of the project declines to the level of the development cost. To offset this phenomenon the option flexibility allows for the risk-reducing effect to protect the owner from substantial risk by letting the option to experience the upside potential (Cappozza and Li, 1994). This does not imply that the cost is fixed at all times since the value option is determined before the cost is calculated so in order to ensure certainty one can use the certainty-equivalent approach.

(c) How Do Variable Costs Affect the Time Conversion of Value Option?

According to the economics principles variable cost stays the same for each unit but then when the production volume changes whether it is increasing or decreasing the total changes. There are different models that are used to measure by how much do variable costs affect the land values. Capozza and Li (1994) concluded that the variable costs of conversion do not affect the rent or the conversion time and this was the result that they received from running a model. They used the Cobb-Douglas function where the unit elasticity of substitution changes density. This means that the changes in the cost of capital are exactly offset by changes in the amount of capital. Therefore their use of the model predicted that higher variable cost lead to low land values. Sebehela (2012) in his analysis concluded that variable cost do add value.

\subsubsection{General Behaviour of Options in the Presence of Financial Parameters}

(a) Do Interest Rates Affect Land Options (i.e. When/What to Build)?

According to economic principles interest rates are extremely volatile and change based on certain aspects. The interest rate a company is offered can reflect the risk of the project, the companies credit/debt history, the current performance of the company or the risk associate with the actual financing based on specific projects. As real estate is such a huge investment, interest rates are very important to look at when financing a development. Interest is a percentage of the total amount borrowed and due to the high magnitude of pricing of real estate, it is important to receive an interest rate that is lower than the profits of the return of the investment. Thus interest rates definitely affect land options and decisions on when and what to build. One cannot afford the opportunity cost of a high interest rate on major capital decisions and thus it may be more beneficial to delay the development process (Black, 1995). Further, interest rate can be view as a "real option". According to Trigeorgis (1996), Interest rates are real options. If one has forecasted interest rates based on risk, availability of lenders etc, it is easy to work out which time period will offer the best payback interest options. This can greatly affect value and reduce costs drastically. Based on interest rates, time to build becomes an opportunity cost of any other time to build, as the cost of lending/financing will differ.

However it is possible to choose an unfavorable interest rate based on other economic advantages in the current market. I intend to prove the actual value discrepancies that interest rates can cause in a project. I also intend to prove the relevance of interest rates as a land option as opposed to other very important variables and how to weigh up the opportunity costs of timing based on acquiring the best interest rate. Timing of decision as a land option takes into account hundreds of relevant variables (i.e. interest rates, demand and investment costs) that affect the land options of when to build. Thus the timing of a decision takes on the inherent market conditions and can affect the best land option.

\section{Methodology}

The Samuelson-McKean (1965) method has in the past been used to estimate the optimal density and the optimal timing of real estate development and it has been used for real options because of its similarity with the real option models. Geltner et al. (2007) suggested using the Samuelson-McKean model to be able to precisely compute the option value and this precision makes the Samuelson-McKean model more suitable for valuing real estate development options in comparison to other closed-form models such as Black-Scholes (1973) equation. More, Samuelson-McKean model is suitable for this research report because of the efficiency demonstrated by the closed-form solution.

Other observations that have been recorded and worth noting as bases of expectations of what is to occur are (a) for the price of the underlying asset, when given an exercise price, the value of a call option increases as the price of the 
underlying asset rises, (b) volatility; holding all other factors equal, the greater the volatility of the underlying asset, the worth of a put or call option will increase, (c) time until expiration; holding all other factors equal, the longer the time until expiration, the higher the value of an option, (d) the level of interest rates; the higher the level of interest rates, the higher the value of a call option, and (e) hen exercising the price of an option; if all other factors held constant, the higher the exercise price, the less calls are worth and the more puts are worth. The Samuelson-McKean formula is as follows;

$$
\eta=\frac{y_{v}-y_{k}+\frac{\sigma_{v}^{2}}{2}+\sqrt{\left(y_{k}-y_{v}-\frac{\sigma_{v}^{2}}{2}\right)^{2}+2 y_{k} \sigma_{v}^{2}}}{\sigma_{v}^{2}}
$$

where $\eta$ denotes the option elasticity, $\mathrm{V}$ is assumed to be the company value $(\mathrm{V})$ is the highest and best suited business for the subject company, and that the cost of running the business, $\mathrm{K}$ corresponds to the highest and best suited business of the company, the option value can be expressed as follows:

$$
C_{0}=\left(V^{*}-K_{0}\right)\left(\frac{V_{0}}{V^{*}}\right)^{\eta}
$$

$V^{*}$ denotes the hurdle value of $\mathrm{V}$ which estimates the optimal timing which is given by:

$$
\begin{gathered}
V^{*}=\frac{K_{0} \eta}{(\eta-1)} \\
\text { and } \\
\eta=\frac{\left\{y-r_{f}+0.5 S^{2}+\left[\left(r_{f}-y-0.5 S^{2}\right)^{2}+2 r_{f} s^{2}\right]^{1 / 2}\right\}}{S^{2}}
\end{gathered}
$$

where $r_{f}$ is the risk-free interest rate, $y$ is the dividend yield rate and $S$ is the volatility of revenues. The model will be used to calculate value under two scenarios when there is cost and in the absence of cost the above variables will be the constant throughout the calculations, these are the crucial variable to the model.

This section lists parameters that are used in the analysis of this dissertation. This includes Liberty Life, Liberty Life financials of over four (2013-2016) years will be used, Liberty's dividends from financials over four years, $\mathrm{V}^{*}$ and $\mathrm{K}$ from financials, land valuation for ERF where Liberty Life is located and risk-free rate from South African Revenue Bank. The calculations for the revenues will be calculated from revenues and expenses. The research study assumes that the company being examined is that which its core business is not real estate and the results of the study will only apply to such businesses. It also assumes that if Liberty Life Group is one of the top 40 companies, then the results will apply to other similar corporates.

\section{Data}

\subsection{Background}

The research report draws data on Liberty Holdings Limited (LBH). The reason why one uses LBH is that it is major South African financial services company which has significant interest in real estate and related industry. In addition, it has been listed on the Johannesburg Stock Exchange (JSE) for decades now. Founded in South Africa as the Liberty Life Association of Africa Ltd by entrepreneur and philanthropist Sir Donald Gordon in 1957, the company's Assets Under Management were worth ZAR 688 billion or USD 53 billion (as at 30 June 2017 and excluding inter-group Life Funds). Liberty is the holding company of various operating subsidiaries engaged in the provision of financial services including long-term and short-term insurance, investment, asset management and health services. Since December 2016, the company effectively owns a majority stake in JSE-listed Liberty Two Degrees (JSE: L2D)-a diversified South African Real Estate Investment Trust (REIT) that owns or co-owns some of the African continent's most valuable commercial real estate including Sandton City. In this data collection we made use of the Municipality of Johannesburg (from here, City of Joburg) municipal valuation roll for the same period as the financial statements, which was derived from 2013 to 2016.

All the data used in this research is based on the company Liberty Life and the building in which the headquarters are operated at. The data in the research is collected from years 2013 to 2016 in which we collected data from sources such as the City Of Joburg municipal valuation roll and Liberty Life's financial statements. The data collected for this research included the companies' revenues, expenses, and the hard/fixed assets. In order to collect data about the land value, we acquired title deeds from the website "winded". The commercial development is "A" grade office building. The vacant land where the building is situated, is valued at R9, 060,000.00 and improvements at R26, 566,666.00 as from July 2013-December 2016 on a yearly basis by City of Joburg. The actual value of this building was not listed on the title 
deed, thus these valuations are based off comparable sales in the area and adjusted for the discrepancies. This calculation was done from years 2014 to 2016 with the most similar comparable sales.

\subsection{Financial Outlook on LBH}

The Liberty Life headquarters is one of the many properties under the Liberty Life real estate fund. Liberty Life has a huge property portfolio. Liberty has invested in all types of property sectors such as retail, hotels, offices and other sectors such as industrial. Below is an illustration of Liberty Life's current property asset holdings and how they are divided:

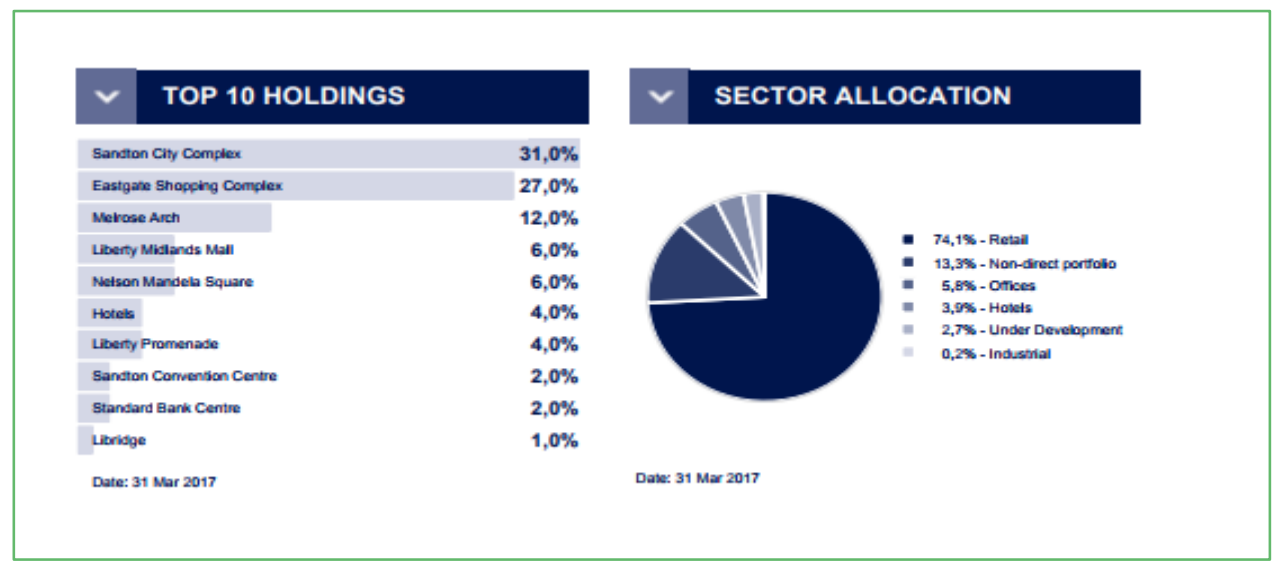

As we can see above Liberty's top property asset holdings are retail and office based such as Sandton city, Eastgate mall and Melrose Arch which include both commercial and retail. However amongst their massive portfolio Liberty hold 5.8\% of all property assets in commercial office buildings which suggests their extensive knowledge in office investments. It is clear that Liberty has no intentions on selling property and rather entices a yield and land appreciation to produce income. Liberty hold huge amounts of the retail and office sector amongst their portfolio, as they believe these two sectors to capitalize on a maximum yield income from these income-generating assets. Thus the return on their investments is much higher and less risky. However of recent times, Liberty Real Estate has launched a new portfolio which will invest only in the shares of the newly created and JSE-listed Liberty REIT. Real estate in Braamfontien has been extremely volatile. There was a huge price peak in 2012 and trough in 2013 throughout all real estate sectors in Braamfontien. The discrepancies in the prices are based on many variables in which we have analysed which effect value. However from the eff valuation, we have seen a steady growth in real estate in Braamfontien from years 2013 to 2016. Below is a graph depicting prices and suburb trends within the headquarter area of Liberty Life;

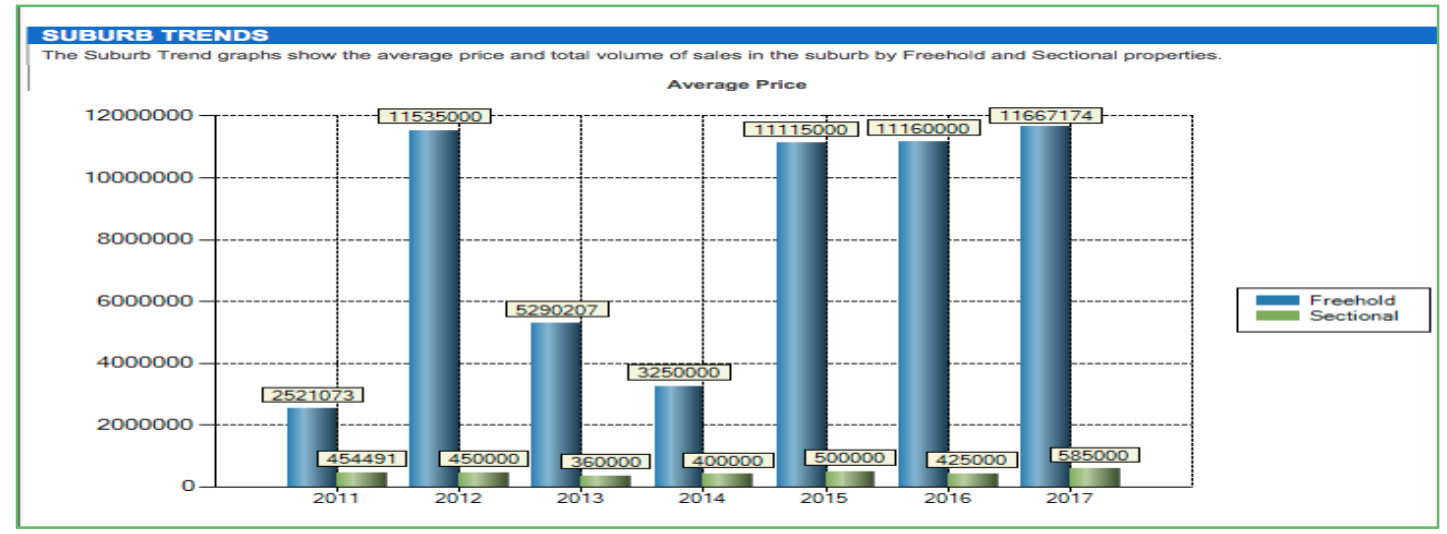

The comparative sales in Braamfontien have been mainly residential and retail developments from 2013 to 2016 which implies a strong youth population growth within the area. The comparable sales are generally a lot smaller than Liberty Life's headquarters and thus adjustments had to be made. 


\section{Empirical Analysis}

\subsection{Input Parameters}

Table 5.1 Aggregate Values

\begin{tabular}{|cccc|}
\hline Aggregate Municipal Value & & & \\
$\mathbf{2 0 1 3}$ & $\mathbf{2 0 1 4}$ & $\mathbf{2 0 1 5}$ & $\mathbf{2 0 1 6}$ \\
R48 450 000,00 & R20 500 000,00 & R20 500 000,00 & R63 000 000,00 \\
R48 450 000,00 & R20 500 000,00 & R 12000000,00 & R 188000000,00 \\
R 48 450 000,00 & R20 500 000,00 & R 150000000,00 & R7 000 000,00 \\
R48 450 000,00 & R20 500 000,00 & R 60833333,33 & R 86000000,00 \\
100 & 100 & 10 & 10 \\
R4 845 000 000,00 & R2 050 000 000,00 & $\mathbf{R 6 0 8 ~ 3 3 3 ~ 3 3 3 , 3 3}$ & R 860 000 000,00 \\
\hline
\end{tabular}

Table 5.1 illustrates that the values of LBH as per the City of Joburg, from 2013-206 have bene increasing on average. Among other questions that value increment bags, is whether the overall company benefits from value increment, this is part of the analysis. Secondly, is the company's CREM strategy aligned with the overall company's strategy? If the answer in the second question is no, then the shareholder's value is not maximized.

\subsection{Estimation of Options Parameters}

The main parameter that needs to be estimated in this research report is the volatility as it affects both the option and the CREM strategy of Liberty Life. Volatility is measured using the total revenue of Liberty Life's statement of comprehensive income. The variances below are of historical values of the corporate's financial statements which is a technique that both Tompkins (2005) and Sebehela (2009) applied. In the table below the standard deviation is calculated to be $0.20 \%$. Therefore, in order to get volatility, the square root of deviations squared is multiplied by the square root of 252 days.

Table 5.2 Volatility Estimation

\begin{tabular}{|cccccc|}
\hline $\begin{array}{c}\text { Volatility Estimation } \\
\text { Date }\end{array}$ & $\begin{array}{c}\text { Revenue/Income } \\
\mathbf{2 0 1 3}\end{array}$ & $\begin{array}{c}\text { Ln (Rev) } \\
\text { R85 } 273000\end{array}$ & Returns & Deviation & (Deviation) $^{\mathbf{2}}$ \\
& 000,00 & & & \\
$\mathbf{2 0 1 4}$ & R79 705000 & 25,10159816 & $-0,067525555$ & 0,034739417 & 0,001206827 \\
& 000,00 & & & & \\
$\mathbf{2 0 1 5}$ & R73 995 000 & 25,02726336 & $-0,074334796$ & 0,027930177 & 0,000780095 \\
& 000,00 & & & & \\
$\mathbf{2 0 1 6}$ & R62 744 000 & 24,86232879 & $-0,164934567$ & $-0,062669595$ & 0,003927478 \\
& 000,00 & & & & \\
Average & & & $-0,102264973$ & & 0,001971467 \\
Square Root & & & & & 1,220831193 \\
\hline
\end{tabular}

Table 5.2 shows that the volatility of Liberty Life between years 2013-2016 is over $100 \%$. This implies that LBH is high risk investment as such; investors who invest in LBH would require higher returns. Whether investors are fairly compensated is beyond the scope of this research. On the other hand, the high volatility would imply that if the CREM strategy and option values are harmonised, shareholder's value should increase and hopefully, this would maximise shareholder's wealth in LBH. 


\subsection{Tests}

Table 5.3 Valuations

\begin{tabular}{|c|c|c|c|c|}
\hline \multirow[t]{2}{*}{$\begin{array}{c}\text { Date as at } 31 \\
\text { December }\end{array}$} & 2013 & 2014 & 2015 & 2016 \\
\hline & R50 999 & R370 430 & R520 906 & \\
\hline Market value & 288,49 & 576,64 & 722,64 & R76 493 998,42 \\
\hline Replacement & R823000 & R29 461000 & R32 048000 & \\
\hline value & 000,00 & 000,00 & 000,00 & R33 828000000,00 \\
\hline Tobin's Q & 0,001710066 & 0,012573591 & 0,016253954 & 0,014085787 \\
\hline $\mathrm{y}=$ initial yield & 87,65 & 11,56 & 8,23 & 5,51 \\
\hline \multirow[t]{2}{*}{$\begin{array}{c}r=\text { risk free } \\
\text { rate, } C P I\end{array}$} & 5.7 & 6.1 & 4.6 & 6.4 \\
\hline & 2013 & 2014 & 2015 & 2016 \\
\hline $\begin{array}{c}\mathrm{V}^{*}= \\
\text { Municipality } \\
\text { values }\end{array}$ & $\begin{array}{c}\mathrm{R} 4845000 \\
000,00\end{array}$ & $\begin{array}{c}\text { R2 } 050000 \\
000,00\end{array}$ & $\begin{array}{c}\text { R608 } 333 \\
333,33\end{array}$ & R860 000 000,00 \\
\hline $\begin{array}{c}\mathrm{K}=\text { fixed } \\
\text { property/hard } \\
\text { assets }\end{array}$ & $\begin{array}{c}\text { R29 } 823000 \\
000,00\end{array}$ & $\begin{array}{c}\text { R29 } 461000 \\
000,00\end{array}$ & $\begin{array}{c}\mathrm{R} 32048000 \\
000,00\end{array}$ & R33 828000000,00 \\
\hline $\begin{array}{l}\mathrm{V}=\text { Market cap } \\
\text { of the company }\end{array}$ & $\begin{array}{c}\text { R50 } 999 \\
288,49\end{array}$ & $\begin{array}{c}\mathrm{R} 370430 \\
576,64\end{array}$ & $\begin{array}{c}\text { R520 } 906 \\
722,64\end{array}$ & R476 493 998,42 \\
\hline Phi & 41821.44868 & 3014.000877 & 2081.103022 & 1985.00589 \\
\hline no costs & $\begin{array}{c}\text { R9 } 079000 \\
000,00\end{array}$ & $\begin{array}{c}\text { R9 } 376000 \\
000,00\end{array}$ & $\begin{array}{l}\text { R10 } 149000 \\
000,00\end{array}$ & R10 733000000,00 \\
\hline total costs & $\begin{array}{c}\text { R4 } 233000 \\
000,00\end{array}$ & $\begin{array}{c}\text { R4 } 579000 \\
000,00\end{array}$ & $\begin{array}{c}\text { R4 } 760000 \\
000,00\end{array}$ & R4 723000000,00 \\
\hline $\begin{array}{l}\text { total costs and } \\
\text { improvements }\end{array}$ & $\begin{array}{c}\text { R13 } 312000 \\
000,00\end{array}$ & $\begin{array}{c}\text { R13 } 955000 \\
000,00\end{array}$ & $\begin{array}{c}\text { R14 } 909000 \\
000,00\end{array}$ & R15 456000000,00 \\
\hline TFC & $\begin{array}{c}\text { R9 } 079000 \\
000,00\end{array}$ & $\begin{array}{l}\text { R9 } 376000 \\
000,00\end{array}$ & $\begin{array}{c}\text { R10 } 149000 \\
000,00\end{array}$ & R10 733000000,00 \\
\hline $\mathrm{VC}$ & $\begin{array}{c}\text { R4 } 233000 \\
000,00\end{array}$ & $\begin{array}{c}\text { R4 } 579000 \\
000,00\end{array}$ & $\begin{array}{c}\text { R4 } 760000 \\
000,00\end{array}$ & R4 723000000,00 \\
\hline
\end{tabular}

In table 5.3 the Tobin Q values were calculated from the years 2013 to 2016. According to the table below if the Tobin $\mathrm{Q}$ is below one then the company must not start construction of any development project within these years. That is, Liberty Life should not have had any development projects constructed within these four years due to the very low Tobin Q values in each year. Sebehela (2012: 431) stated that "basically according to the Tobin's Q calculations, any month from March 2006 to February 2007, was the right time to start the construction of the office building as the Tobin's Q is greater than one". Given that Tobin Qs are less than one, it implies that the construction of the Liberty Life's building should be having been postponed until the "Right" time, i.e. Tobin Qs must be at least ones. Therefore, at that time based on the construction that took place including acquisitions of new properties as illustrated on the financial statements should have been postponed. Further, table 5.3 shows the aggregate municipal values from the years 2013 to 2016. These values are from the sale of the comparable properties near Liberty Life. The Liberty Life building is approximately 34000 meters squared, therefore the aggregate municipal values for 2013 and 2014 are multiplied by 100 to account for the size $\left(250 \mathrm{~m}^{2}\right)$ of the land of the comparable properties. As well as the years 2015 and 2016 have been multiplied by 10 to account for the difference in the land size $\left(2400 \mathrm{~m}^{2}\right)$ of the comparable properties. The table above the aggregate municipal values illustrates the land value of the option when there are no costs (FC), total costs (TVC) and total costs with improvements (TVC + FC). When there are no costs the option value 
is the same price as the business's fixed costs. This is also similar when applying the calculation to the total costs, as the option values is the same price as the business's total variable costs. The same principle is applied to the scenario of when there are improvements. However, it is seen that the option value increases each year, as well as when variables are added the value of the option will increase for each year while there is only one slight decrease when costs are included in the year 2016.

Finally, option values be variable cost of total costs, show an increasing trajectory on average, implying the value of land options increasing with an increase in underlying asset. However, the variable costs do not always increase with an increase with underlying assets. One of the reasons for that, is that some of the cost can be planned in advance which leads to hedging of options values. The above results illustrate that despite that in certain situations, CRE can be seen as overbuilding-the option value contribution is phenomenal. The latter phenomenon can be inferred from Grenadier (1996). Broadly, results show that CRE is a value-adding asset if properly manged and aligned with the rest of the business units of a firm. That is, CRE should not be regarded as a stand-alone asset class. Given that Liberty Life is a wholesale financial service company with exposure to different sectors, the results are most likely to apply to other sectors in which Liberty is invested in.

\section{Conclusion}

To sum up; firstly, this article illustrates that it is better to manage CRE internally than to outsource it. Secondly, it is slightly cheaper to manage CRE internally-benefits and costs can be "hedged". Thirdly, as a real option, CRE increases the value of a firm. Finally, the value of an option can be as high as ten times the value of the CRE business unit.

The implications of this study are CRE unit must be aligned with the rest of business units in the company. Secondly, the optionality that emerges from CRE should be accounted for. Thirdly, shareholders' wealth is maximized when all business units are appropriately managed together.

Future research should explore how different business units including CRE contribute to the wealth of shareholders. More, at what point is each business unit's value contribution being maximised.

\section{References}

Arnold, T., \& Crack, T. F. (2000). Option Pricing in the Real World: A Generalized Binomial Model with Applications to Real Options. Working Paper.

Bowman, E. H., \& Moskowitz, G. T. (2001). Real Options Analysis and Strategic Decision Making. Organization Science, 12(6), 772-777. https://doi.org/10.1287/orsc.12.6.772.10080

Capozza, D., \& Li, Y. (1994). The Intensity and Timing of Investment: The Case of Land. American Economic Review, 84(4), 889-904.

Chiang, Y. H., Joinkey, S. C. K., \& Stanley, Y. C. W. (2006). Real Option Premium in Hong Kong Land Prices. Journal of Property Investment \& Finance, 24(3), 239-258. https://doi.org/10.1108/14635780610659946

Cox, J. C., \& Rubinstein, M. (1985). Options markets. Prentice Hall.

Damaraju, N. L., Barney, J. B., \& Makhija, A. K. (2015). Real Options in Divestment Alternatives. Strategic Management Journal, 36(5), 728-744. https://doi.org/10.1002/smj.2243

De Jonge, H. (1996). Toegevoegde Waarde Van Concemhuisvesting, Paper Presented at NSC Conference, October 15 1996.

Gibler, K. M., \& Lindholm, A. L. (2012). A Test of Corporate Real Estate Strategies and Operating Decisions in Support of Core Business Strategies. Journal of Property Research, 29(1), 25-48. https://doi.org/10.1080/09599916.2011.608470

Gibler, K., \& Black, R. (2004). Agency Risks in Outsourcing Corporate Real Estate Functions. Journal of Real Estate Research, 26(2), 137-160.

Grenadier, S. R. (1996). The Strategic Exercise of Options: Development Cascades and Overbuilding in Real Estate Markets. Journal of Finance, 51(5), 1653-1679. https://doi.org/10.1111/j.1540-6261.1996.tb05221.x

Krumm, P. J., \& Linneman, P. (2001). Corporate Real Estate management. Wharton Real Estate Review. Working Paper.

Lambrecht, B., \& Perraudin, W. (2003). Real Options and Preemption under Incomplete Information. Journal of Economic Dynamics \& Control, 27(4), 619-643. https://doi.org/10.1016/S0165-1889(01)00064-1

Martins, J., Marques, R. C., \& Cruz, C. O. (2013). Real Options in Infrastructure: Revisiting the Literature. Journal of Infrastructure Systems, 21(1), p.04014026. https://doi.org/10.1061/(ASCE)IS.1943-555X.0000188 
Matsham, A., \& Heywood, C. (2012). An Investigation of Corporate Real Estate Management Outsourcing in Melbourne. In 18th Annual Pacific-Rim Real Estate Society Conference, Adelaide, Australia.

Regan, C. M., Bryan, B. A., Connor, J. D., Meyer, W. S., Ostendorf, B., Zhu, Z., \& Bao, C. (2015). Real Options Analysis for Land use Management: Methods, Application, and Implications for Policy. Journal of Environmental Management, 161, 144-152. https://doi.org/10.1016/j.jenvman.2015.07.004

Samuelson, P. A. (1965). Rational Theory of Warrant Pricing. Industrial Management Review (pre-1986), 6(2), p.13.

Sebehela, T. (2012). ROA of Real Estate Development in ZA. Journal of Modern Accounting and Auditing, 8(3), 424-434

Titman, S. (1985). Urban Land Prices Under Uncertainty. American Economic Review, 75(3), 505-514.

Trigeorgis, L. (1996). Real Options, MIT Press

\section{Copyrights}

Copyright for this article is retained by the author(s), with first publication rights granted to the journal.

This is an open-access article distributed under the terms and conditions of the Creative Commons Attribution license which permits unrestricted use, distribution, and reproduction in any medium, provided the original work is properly cited. 